\title{
Copper Nitrate Redispersion To Arrive at Highly Active Silica-Supported Copper Catalysts
}

\author{
P. Munnik, ${ }^{\dagger}$ M. Wolters, ${ }^{+, \ddagger}$ A. Gabrielsson, ${ }^{\S, \|}$ S. D Pollington, ${ }^{\perp}$ G. Headdock, ${ }^{\S}$ J. H. Bitter, ${ }^{\dagger}$ \\ P. E. de Jongh, ${ }^{\dagger}$ and K. P. de Jong, ${ }^{*}+$ \\ ${ }^{\dagger}$ Inorganic Chemistry and Catalysis, Debye Institute for Nanomaterials Science, Utrecht University, Universiteitsweg 99, \\ Post Office Box 80083, 3508 TB Utrecht, The Netherlands \\ ${ }^{\S}$ Chemical Catalysis and ${ }^{\perp}$ Johnson Matthey Technology Centre, Johnson Matthey Catalysts, Belasis Avenue, Post Office Box 1, \\ Billingham TS23 1LB, United Kingdom
}

ABSTRACT: In order to obtain copper catalysts with high dispersions at high copper loadings, the gas flow rate and gas composition was varied during calcination of silica gel impregnated with copper nitrate to a loading of $18 \mathrm{wt} \%$ of copper. Analysis by $\mathrm{X}$-ray diffraction (XRD), $\mathrm{N}_{2} \mathrm{O}$ chemisorption, and transmission electron microscopy (TEM) showed that calcination in stagnant air resulted in very large copper crystallites and a low copper surface area $\left(12 \mathrm{~m}^{2} \cdot \mathrm{g}_{\mathrm{Cu}}{ }^{-1}\right)$. A moderate flow of air was sufficient to greatly enhance the copper surface area $\left(\sim 90 \mathrm{~m}^{2} \cdot \mathrm{g}_{\mathrm{Cu}}{ }^{-1}\right)$ based on a

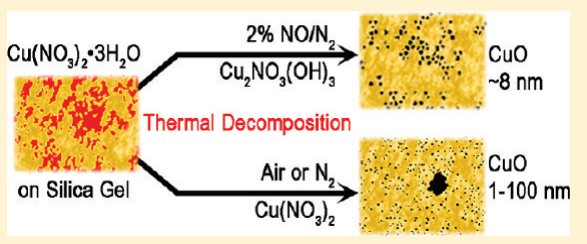
bimodal particle size distribution of few large crystallites and a highly dispersed phase. Changing to an $\mathrm{N}_{2}$ flow resulted in similar copper surface areas compared to samples calcined in air at the same space velocity, while calcination in a $2 \% \mathrm{NO} / \mathrm{N}_{2}$ flow resulted in a relatively narrow particle size distribution peaking around $8 \mathrm{~nm}$ and a slightly lower copper surface area $\left(84 \mathrm{~m}^{2} \cdot \mathrm{g}_{\mathrm{Cu}}{ }^{-1}\right) . \mathrm{By} \mathrm{use} \mathrm{of}$ SBA-15 supported samples, in situ XRD and diffuse reflectance Fourier transform infrared spectroscopy (DRIFTS) showed that the decomposition of copper nitrate in $\mathrm{NO}$ occurred via a highly dispersed copper hydroxynitrate phase, while decomposition in $\mathrm{N}_{2}$ or air occurred partly via copper nitrate anhydrate and partly via poorly dispersed copper hydroxynitrate. The high CuO dispersions after calcination in an $\mathrm{N}_{2}$ or air flow were ascribed to the redispersion of copper nitrate anhydrate by interaction with the OH groups of the silica support. By utilization of this redispersion, high copper dispersions on silica gel with concomitant high activities were obtained for the gas-phase hydrogenation of butanal.

\section{INTRODUCTION}

Supported copper nanoparticles are widely applied because of their high activity in reactions such as hydrogenation of aldehydes and dehydrogenation of alcohols, ${ }^{1-8}$ toluene oxidation, ${ }^{9}$ water-gas shift reaction, ${ }^{10,11}$ hydrogenolysis of esters, ${ }^{12,13}$ and production of methanol from synthesis gas. ${ }^{14-17}$ Copper catalysts are often prepared via coprecipitation, as high loadings can be achieved in combination with high copper dispersion and good stability. ${ }^{13-15,18}$ Alternative methods have been explored such as chemical vapor deposition, ${ }^{19,20}$ colloidal routes, ${ }^{21}$ and sol-gel synthesis. ${ }^{22}$ Preparation via pore volume impregnation is especially desirable because of its practical simplicity and small waste streams. For this method a number of metal precursors are available, including copper citrate, acetate, chloride, and nitrate. The use of the latter precursor is generally preferred because of its low cost, high solubility in water, and facile removal of the anion. However, metal particles prepared from nitrates are generally large $(>10 \mathrm{~nm})$, which has been ascribed to agglomeration during the drying and calcination step. $2,23-25$

A number of methods to counter agglomeration of transition metal nitrates such as nickel, cobalt, and copper nitrate have been reported, including replacement of the air calcination by glow discharge plasma-assisted nitrate decomposition ${ }^{26}$ and direct reduction of the metal nitrate to the metal, omitting air thermal treatment. ${ }^{5,25,27,28}$ Another approach is fast removal of the decomposition gases via high space velocities or evacuation. ${ }^{24,29}$ We have previously reported that agglomeration of cobalt and nickel nitrate can effectively be prevented by replacing traditional air calcination with thermal treatment in $1 \%(\mathrm{v} / \mathrm{v}) \mathrm{NO} / \mathrm{He}$ flow, resulting in high $\mathrm{NiO}$ and $\mathrm{Co}_{3} \mathrm{O}_{4}$ dispersions. ${ }^{30,31}$ For silicasupported copper nitrate, it was reported that the drying step is of vital importance to the particle size distribution. ${ }^{5}$ Drying at elevated temperatures resulted in agglomeration during the hydrolysis of copper nitrate hydrate to copper hydroxynitrate. $5,32,33$ Drying at ambient temperatures prevented the formation of large copper hydroxynitrate crystals, but subsequent calcination still resulted in broad particle size distributions. Direct reduction of room temperature-dried samples yielded a higher $\mathrm{Cu}$ dispersion but is generally not preferred due to the exothermic formation of ammonia. It is therefore desirable to obtain high $\mathrm{CuO}$ dispersions via a calcination method.

In this paper, the impact of the gas flow and gas composition during calcination on the final copper metal surface area and catalytic activity for butanal hydrogenation was studied. Two silica supports were investigated: silica gel was used related to its industrial relevance and the need for particle sieve fractions for

Received: December 11, 2010

Revised: June 22, 2011

Published: July 12, 2011 
catalysis, while SBA-15 was used as a model support ${ }^{34}$ to facilitate characterization studies, in particular transmission electron microscopy (TEM). Subsequent in situ X-ray diffraction (XRD) and diffuse reflectance Fourier transform infrared spectroscopy (DRIFTS) studies were performed to identify the reason for the differences in particle size and distribution obtained under different experimental conditions.

\section{EXPERIMENTAL SECTION}

Catalyst Preparation. Davicat 1404 silica gel, supplied by Grace Davidson [Brunauer-Emmett-Teller (BET) surface area $=553 \mathrm{~m}^{2} \cdot \mathrm{g}^{-1}$, pore volume $=0.9 \mathrm{~mL} \cdot \mathrm{g}^{-1}$, pore diameter $=$ $7 \mathrm{~nm}$ ], was sieved to a particle size of $200-400 \mu \mathrm{m}$. Samples containing 18 wt $\% \mathrm{Cu}$ were prepared by impregnation of the sieved silica support to incipient wetness with a $4 \mathrm{M}$ copper nitrate solution (acidified to $\mathrm{pH} 1$ with $\mathrm{HNO}_{3}$ ). After an equilibration time of $15 \mathrm{~min}$, two different routes were taken. The first route involved transfer to a tubular reactor, where the sample was dried at room temperature for $15 \mathrm{~min}$ in a flow of $2 \% \mathrm{NO} / \mathrm{N}_{2}$, air, or $\mathrm{N}_{2}$ and subsequently heated to $350{ }^{\circ} \mathrm{C}\left(2^{\circ} \mathrm{C} \cdot \mathrm{min}^{-1}\right)$ in the same gas flow for $30 \mathrm{~min}$. In addition, the gas hourly space velocity (GHSV) during thermal treatment was varied from 0 to $15000 \mathrm{~h}^{-1}$. Samples are denoted CuSG- $x$, where $x$ stands for the GHSV used during calcination in air. Samples calcined in $\mathrm{N}_{2}$ and $\mathrm{NO}$ at a GHSV of $15000 \mathrm{~h}^{-1}$ are denoted CuSG-N $\mathrm{N}_{2}$ and CuSG$\mathrm{NO}$, respectively. Alternatively, the impregnate was dried at $120{ }^{\circ} \mathrm{C}$ in static air for $16 \mathrm{~h}$ before calcination in a flow of air at a GHSV of $15000 \mathrm{~h}^{-1}$. This sample is called CuSG-120-air.

SBA-15 (BET surface area $705 \mathrm{~m}^{2} \cdot \mathrm{g}^{-1}$, pore volume $0.8 \mathrm{~cm}^{3}$. $\mathrm{g}^{-1}$, pore diameter $9 \pm 0.5 \mathrm{~nm}$, particle diameter $\left.1-5 \mu \mathrm{m}\right)^{35}$ samples containing $17 \mathrm{wt} \% \mathrm{Cu}$ were prepared by impregnation to incipient wetness with a $4 \mathrm{M}$ copper nitrate solution (acidified to $\mathrm{pH} 1$ with $\mathrm{HNO}_{3}$ ). After impregnation the sample was dried in a desiccator at room temperature for $24 \mathrm{~h}$, followed by in situ DRIFT measurements or calcination in a tubular reactor in air or $2 \% \mathrm{NO} / \mathrm{N}_{2}$ at a GHSV of $15000 \mathrm{~h}^{-1}$. The latter samples are denoted CuSBA-air and CuSBA-NO, respectively. The samples used for the in situ XRD experiments and TEM were impregnated with a $3 \mathrm{M}$ instead of $4 \mathrm{M}$ solution, leading to $13 \mathrm{wt} \% \mathrm{Cu}$ loading.

Characterization. XRD patterns from $20^{\circ}$ to $60^{\circ} 2 \theta$ were obtained at room temperature with a Bruker-Nonius D8 Advance $\mathrm{X}$-ray diffractometer setup using $\mathrm{Co}_{\mathrm{O}} \mathrm{K}_{\alpha 12}(\lambda=1.79026 \AA)$ radiation. The diffraction patterns were normalized to the intensity of the amorphous silica scattering band. Average crystallite sizes were calculated from XRD line broadening by use of the Debye-Scherrer equation. For in situ XRD experiments, the Bruker-Nonius D8 Advance X-ray diffractometer was equipped with an Anton-Paar XRK reaction chamber. In a typical experiment the dried impregnate $(40 \mathrm{mg})$ was heated in a $10 \%$ $\mathrm{O}_{2} / \mathrm{N}_{2}$ or a $10 \% \mathrm{NO} / \mathrm{He}$ flow $\left(90 \mathrm{~mL} \cdot \mathrm{min}^{-1}\right)$ to $350{ }^{\circ} \mathrm{C}$ with a ramp of $1^{\circ} \mathrm{C} \cdot \mathrm{min}^{-1}$.

TEM images of the CuSG samples were obtained on a Technai 12 apparatus, operated at $120 \mathrm{keV}$. The CuSG catalyst particles were embedded in a two-component epoxy resin (Epofix, EMS) and cured at $60{ }^{\circ} \mathrm{C}$ overnight. The embedded catalysts were cut into thin sections with a nominal thickness of $50 \mathrm{~nm}$ by use of a Diatome Ultra $35^{\circ}$ diamond knife mounted on a Reichert-Jung Ultracut $\mathrm{E}$ microtome. The sections were then collected on a TEM grid. The CuSBA samples were imaged on a Technai 20 apparatus, operating at $200 \mathrm{keV}$ and equipped with an energy-dispersive
X-ray (EDX) detector. Nickel grids were used so that the copper distribution could be studied.

The copper surface area was determined via $\mathrm{N}_{2} \mathrm{O}$ chemisorption at $68{ }^{\circ} \mathrm{C}$ after reduction at $230{ }^{\circ} \mathrm{C}$; an $\mathrm{N}_{2} \mathrm{O}: \mathrm{Cu}$ stoichiometry of 0.5 and a copper surface atom density of $1 \times 10^{19}$ atoms $\cdot \mathrm{m}^{-2}$ were assumed. The copper particle diameter $\left(d_{\mathrm{Cu}}\right.$ in nanometers) was calculated by assuming a spherical particle shape and using the equation:

$$
d_{\mathrm{Cu}}(\mathrm{nm})=\frac{6000}{S \rho_{\mathrm{Cu}}}
$$

with $S=$ copper specific surface area (square meters per gram) and $\rho_{\mathrm{Cu}}=$ copper density $\left(8.92 \mathrm{~g} \cdot \mathrm{cm}^{-3}\right)$.

In situ DRIFTS measurements were performed with a Bruker Tensor 27 apparatus utilizing a HVC-DRP-3 diffuse reflectance reaction chamber with $\mathrm{CaF}_{2}$ windows and an mercurycadmium - telluride (MCT) detector. The bottom of the sample cup was filled with silicon carbide and covered by a grid to minimize temperature gradients, creating a cup of about $1-2 \mathrm{~mm}$ deep for the sample $( \pm 15 \mathrm{mg})$. Gas flowed through the sample from top to bottom at a flow rate of $10 \mathrm{~mL} \cdot \mathrm{min}^{-1}$. The different gases used during the experiments were $20 \% \mathrm{O}_{2} / \mathrm{N}_{2}$, pure $\mathrm{N}_{2}$, $10 \% \mathrm{NO} / \mathrm{He}$, and $1 \% \mathrm{NO} / \mathrm{He}$. Fifty scans were recorded from 4000 to $1000 \mathrm{~cm}^{-1}$ at a resolution of $4 \mathrm{~cm}^{-1}$. Spectra were taken at 2-min intervals. In a typical experiment the cell was first flushed with $\mathrm{N}_{2}$ at ambient temperature for $10 \mathrm{~min}$, followed by introduction of the proper gas flow. After a 10 min equilibration, the temperature was raised to $350^{\circ} \mathrm{C}$ with a ramp of $1{ }^{\circ} \mathrm{C} \cdot \mathrm{min}^{-1}$.

Catalytic Testing. The silica-gel based catalysts were tested for gas-phase hydrogenation of butanal. Typically $200 \mathrm{mg}$ of catalyst was mixed with $500 \mathrm{mg}$ of silicon carbide and loaded into a $1 / 4$-in. diameter reactor. Quartz wool was used to support the catalyst bed. Prior to the reaction, the catalysts were reduced at $230{ }^{\circ} \mathrm{C}$ at a pressure of 2 bar in a $400 \mathrm{~mL} \cdot \mathrm{min}^{-1} 2 \% \mathrm{H}_{2} / \mathrm{N}_{2}$ flow. After activation, the 2 bar pressure was maintained and the temperature decreased to $160{ }^{\circ} \mathrm{C}$. The reaction was started by feeding butanal $(98 \%)$ with a liquid flow rate of $0.167 \mathrm{~mL} \cdot \mathrm{min}^{-1}$ [liquid hourly space velocity $(\mathrm{LHSV})=25 \mathrm{~h}^{-1}$ ] and $\mathrm{H}_{2}$ with a flow rate of $400 \mathrm{~mL} \cdot \mathrm{min}^{-1}\left(\mathrm{H}_{2} /\right.$ butanal $\left.=10 \mathrm{~mol} / \mathrm{mol}\right)$. The hydrogenation was done at $160^{\circ} \mathrm{C}$ for $72 \mathrm{~h}$, followed by $24 \mathrm{~h}$ at $150{ }^{\circ} \mathrm{C}$. The yield and selectivity were determined via liquid sample analysis on a HP6890 series gas chromatography (GC) apparatus.

\section{RESULTS}

Structural Characterization. Thermal decomposition of silicasupported copper nitrate catalysts was studied by variation of the gas composition and gas flow, and the resulting samples were characterized by XRD, $\mathrm{N}_{2} \mathrm{O}$ chemisorption, and TEM. An overview of the $\mathrm{CuO}$ crystallite sizes after calcination and $\mathrm{Cu}$ surface areas and calculated $\mathrm{Cu}$ particle sizes after reduction is given in Table 1.

Gas Flow: Silica Gel Support. Line broadening analysis on $\mathrm{CuO}$ diffraction lines suggested poorly dispersed $\mathrm{CuO}$ was obtained after calcination, irrespective of the flow rate. However, the intensity of the sharp diffraction lines, as normalized on the silica scattering band (Figure 1), indicated variation in the amount of crystalline material between samples. Since XRD analysis can only detect crystalline material, it is likely that the samples calcined in a high air flow contained a large fraction of amorphous or highly dispersed $\mathrm{CuO}$. Thus, while XRD analysis on the 
Table 1. Sample Preparation, Designation, and Physical Properties ${ }^{a}$

\begin{tabular}{|c|c|c|c|c|c|c|c|}
\hline \multirow[b]{2}{*}{ sample } & drying & \multicolumn{3}{|c|}{ calcination } & \multicolumn{3}{|c|}{ physical properties } \\
\hline & gas, temp, duration & $\begin{array}{l}\text { temp }^{b} \\
\left({ }^{\circ} \mathrm{C}\right)\end{array}$ & $\begin{array}{c}\text { gas } \\
\text { atmosphere }\end{array}$ & $\begin{array}{l}\text { GHSV } \\
\left(\mathrm{h}^{-1}\right)\end{array}$ & $\begin{array}{l}\mathrm{CuO} \text { crystallite size } \\
(\mathrm{nm})\end{array}$ & $\begin{array}{c}\text { Cu surface area } \\
\left(\mathrm{m}^{2} \cdot \mathrm{g}_{\mathrm{Cu}}{ }^{-1}\right)\end{array}$ & $\begin{array}{c}\text { Cu particle size } \\
(\mathrm{nm})\end{array}$ \\
\hline CuSG-0 & air flow, RT, $15 \mathrm{~min}$ & 350 & air & 0 & 36 & 12 & 55 \\
\hline CuSG-250 & air flow, RT, $15 \mathrm{~min}$ & 350 & air & 250 & 34 & 88 & 7.6 \\
\hline CuSG-1000 & air flow, RT, $15 \mathrm{~min}$ & 350 & air & 1000 & 30 & 85 & 7.9 \\
\hline CuSG-5000 & air flow, RT, $15 \mathrm{~min}$ & 350 & air & 5000 & 28 & 91 & 7.3 \\
\hline CuSG-15000 & air flow, RT, $15 \mathrm{~min}$ & 350 & air & 15000 & 20 & 110 & 6.0 \\
\hline $\mathrm{CuSG}-\mathrm{N}_{2}$ & $\mathrm{~N}_{2}$ flow, RT, $15 \mathrm{~min}$ & 350 & $\mathrm{~N}_{2}$ & 15000 & 28 & 108 & 6.2 \\
\hline CuSG-NO & $2 \% \mathrm{NO} / \mathrm{N}_{2}$ flow, $\mathrm{RT}, 15 \mathrm{~min}$ & 350 & $2 \% \mathrm{NO} / \mathrm{N}_{2}$ & 15000 & 8.5 & 84 & 8.0 \\
\hline CuSG-120-air & stagnant, ${ }^{c} 120^{\circ} \mathrm{C}, 16 \mathrm{~h}$ & 350 & air & 15000 & 20 & 106 & 6.3 \\
\hline CuSBA-air & desiccator, ${ }^{c} \mathrm{RT}, 24 \mathrm{~h}$ & 350 & air & 15000 & 23 & 130 & 5.2 \\
\hline CuSBA-NO & desiccator, ${ }^{c} \mathrm{RT}, 24 \mathrm{~h}$ & 350 & $2 \% \mathrm{NO} / \mathrm{N}_{2}$ & 15000 & 6.5 & 120 & 5.6 \\
\hline
\end{tabular}

${ }^{a} \mathrm{CuO}$ crystallite size was calculated from XRD line broadening analysis of the calcined catalysts, and copper surface area and particle size were determined from $\mathrm{N}_{2} \mathrm{O}$ chemisorption of the reduced catalysts. ${ }^{b}$ The temperature ramp during thermal treatment was $2{ }^{\circ} \mathrm{C} \cdot \min { }^{-1}{ }^{c}$ Dried prior to loading into the reactor.

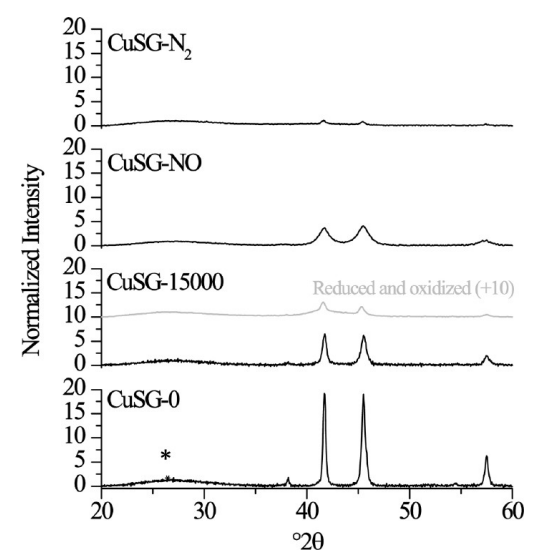

Figure 1. $\mathrm{CuO}$ diffraction patterns of CuSG samples: (black lines) after calcination, as a function of gas atmosphere and flow rate, and (gray line) after reduction and reoxidation of CuSG-15000. The intensities have been normalized to that of the amorphous $\mathrm{SiO}_{2}$ scattering band $\left(^{*}\right)$.

sample obtained via calcination at a GHSV of $15000 \mathrm{~h}^{-1}$ (CuSG15000 ) suggested a poorly dispersed catalyst, the low-intensity diffraction lines could indicate that a bimodal particle size distribution was actually obtained.

To study the dispersion, the $\mathrm{Cu}$ surface area of reduced catalysts was determined by $\mathrm{N}_{2} \mathrm{O}$ chemisorption (Table 1 ). Temperature-programmed reduction (TPR) experiments (data not shown) confirmed that in each case the conditions used resulted in complete reduction of all $\mathrm{CuO}$. The $\mathrm{Cu}$ specific surface area of the sample calcined in stagnant air (CuSG-0) showed a low value, in line with the large $\mathrm{CuO}$ crystallites found with XRD. The corresponding calculated $\mathrm{Cu}$ particle size was even larger, which could point to polycrystalline $\mathrm{CuO}$ particles after calcination. However, a low gas flow was already found to be sufficient to greatly enhance the copper surface area, and a further gradual increase in surface area was observed with increasing space velocity. These results contradict the XRD data and show that XRD line broadening analysis alone was not a reliable characterization method to study this catalyst system. This poor correlation could be explained by a highly dispersed or amorphous phase and indicates a bimodal distribution was obtained in these cases.

To further investigate this, the diffraction pattern of CuSG15000 after reduction and reoxidation is shown in Figure 1. The same sharp peaks were observed as in the calcined sample; however, they are now superimposed on top of a broad base. This suggests part of the $\mathrm{CuO}$ was undetectable before reduction and reoxidation because it was amorphous or consisted of too-small crystallites that became larger or more crystalline after reduction and subsequent reoxidation.

Gas Composition: Silica Gel Support. When air was changed to an $\mathrm{N}_{2}$ flow while the GHSV was kept constant at $15000 \mathrm{~h}^{-1}$, $\mathrm{XRD}$ results indicated even less crystalline material (Figure 1) was obtained. This suggested even fewer of the large crystallites had been formed and that almost all the copper oxide was amorphous or highly dispersed. On the contrary, calcination in a flow of $2 \% \mathrm{NO} / \mathrm{N}_{2}$ (CuSG-NO) did not result in sharp peaks but rather in broad diffraction lines, indicating smaller and more uniform crystallites were obtained. Moreover, integration of the normalized peaks suggested the $\mathrm{CuO}$ crystallinity after calcination in NO was higher compared to CuSG-N 2 and CuSG-15000.

$\mathrm{N}_{2} \mathrm{O}$ chemisorption results for the samples heat-treated in an air flow or $\mathrm{N}_{2}$ flow showed few differences; both samples exhibited very high $\mathrm{Cu}$ surface areas and small derived $\mathrm{Cu}$ particle sizes (Table 1). This was surprising since the XRD diffraction patterns showed a significant decrease in $\mathrm{CuO}$ intensity and indicated that heat treatment in an $\mathrm{N}_{2}$ flow led to higher overall dispersions. A tentative explanation could involve the more abundant large crystallites found for CuSG-15000 combined with the more finely dispersed or amorphous phase compensated to arrive at similar copper surface areas. For the sample calcined in 2\% NO/ $\mathrm{N}_{2}$, the $\mathrm{CuO}$ crystallite size and the $\mathrm{Cu}$ particle size derived from $\mathrm{XRD}$ and $\mathrm{N}_{2} \mathrm{O}$ chemisorption coincided, indicating that the $\mathrm{CuO}$ crystallite size found with XRD was in this case close to the particle size after reduction. The $\mathrm{Cu}$ surface area of the latter was lower than of those heat-treated in air or $\mathrm{N}_{2}$ at the same flow rates linked to a larger average particle size.

TEM analysis on CuSG- $\mathrm{N}_{2}$ and CuSG-NO before and after reduction and reoxidation confirmed these results. CuSG-N showed hardly any $\mathrm{CuO}$ on the silica support (Figure 2A). 


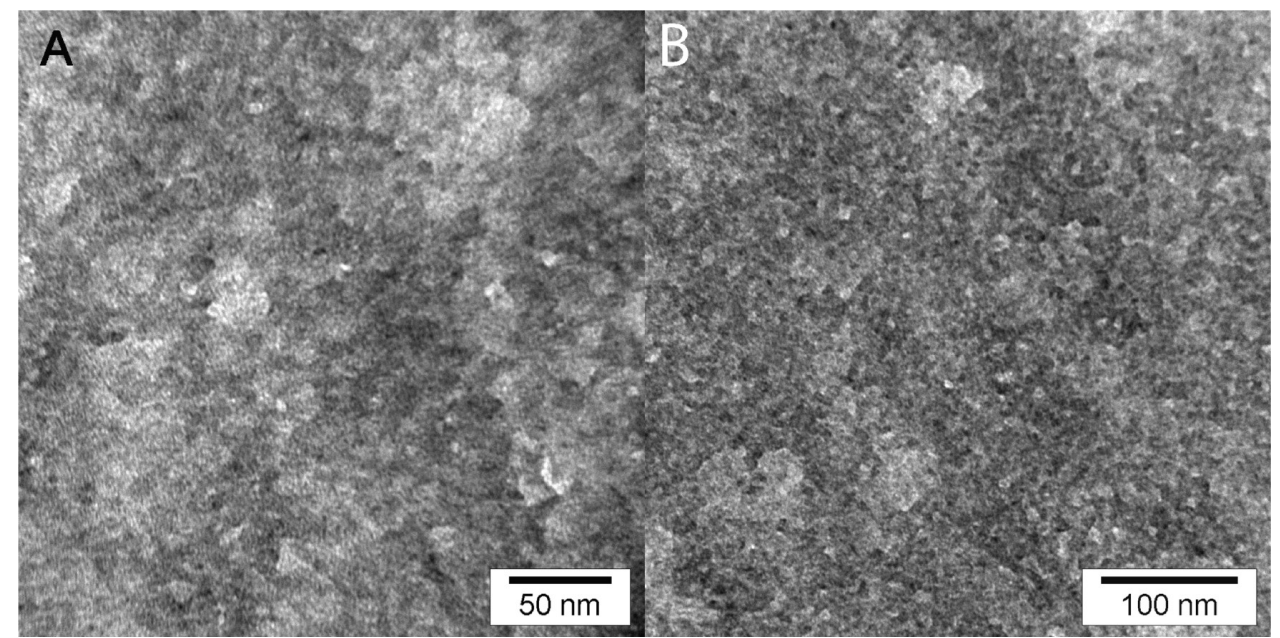

Figure 2. TEM images of CuO/SG: (A) after heat treatment in $\mathrm{N}_{2}$ at a GHSV of $15000 \mathrm{~h}^{-1}$, followed by (B) reduction and reoxidation.

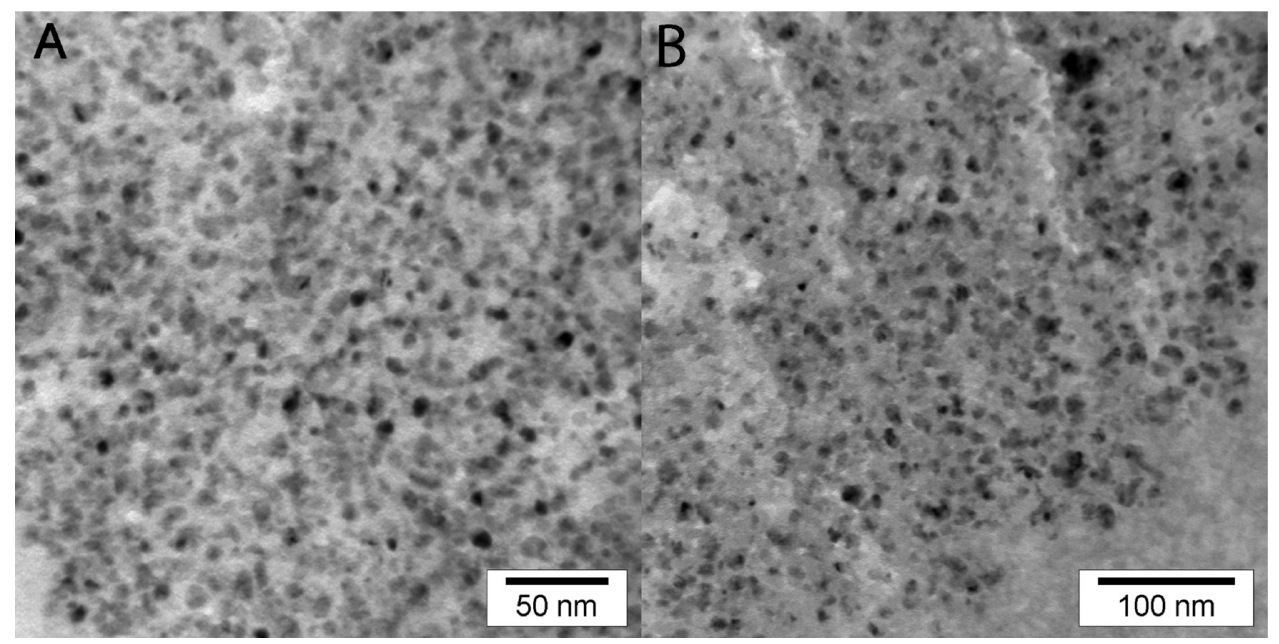

Figure 3. TEM images of $\mathrm{CuO} / \mathrm{SG}$ : (A) after heat treatment in $2 \% \mathrm{NO} / \mathrm{N}_{2}$ at a GHSV of $15000 \mathrm{~h}^{-1}$, followed by (B) reduction and reoxidation.

However, after reduction and reoxidation, small $\mathrm{CuO}$ particles were found homogeneously distributed throughout the support (Figure 2B). The $\mathrm{CuO}$ particles were well dispersed before reduction and reoxidation and therefore undetected by XRD. On the other hand, CuSG-NO showed many particles with an average size of $8.5 \mathrm{~nm}$, which were retained after reduction and reoxidation (Figure 3). This coincided well with the results from XRD and $\mathrm{N}_{2} \mathrm{O}$ chemisorption, suggesting CuSG-NO exhibited a monomodal particle size distribution rather than a bimodal one. In addition, the distribution of copper particles over the support was found to be inhomogeneous. Large areas of sometimes $1 \mu \mathrm{m}$ across showed a higher local copper loading where the copper particles were close together, while other areas of the support were almost empty, as has been observed before for nickel on SBA-15. ${ }^{36}$

Previously it has been reported that drying of silica impregnated with copper nitrate at elevated temperatures $\left(\geq 90^{\circ} \mathrm{C}\right)$ in stagnant air results in broad particle size distributions, due to the formation of large copper hydroxynitrate crystals. ${ }^{5,32}$ We investigated the effect of this drying treatment on the copper surface area by comparison of the CuSG-15000 sample, which had been dried in a flow of air at room temperature, with a sample that had been dried at $120^{\circ} \mathrm{C}$ in stagnant air followed by calcination in an air flow (CuSG-120-air, GHSV $=15000 \mathrm{~h}^{-1}$ ). After drying, XRD confirmed large copper hydroxynitrate crystals had formed. However, as shown in Table 1 , no significant difference in copper surface area was observed between the two samples after calcination, suggesting partial redispersion must have occurred during calcination in an air flow.

SBA-15 Support. A comparison was made with the model silica support SBA-15, which allowed for better TEM analysis of the $\mathrm{CuO}$ particle distribution due to its ordered pore structure and smaller mesoscopic particle size. While these differences compared to silica gel could result in more facile water removal during drying and decomposition and thus could have an influence on precursor mobility and agglomeration, $\mathrm{XRD}$ and $\mathrm{N}_{2} \mathrm{O}$ chemisorption measurements showed similar results as with silica gel (Table 1). The XRD pattern of CuSBA-air is comparable to that of CuSG-15000 and suggested that few large copper agglomerates were present, while $\mathrm{N}_{2} \mathrm{O}$ chemisorption reported a very high copper surface area suggesting the majority of copper was highly dispersed. For CuSBA-NO, XRD and $\mathrm{N}_{2} \mathrm{O}$ chemisorption results 


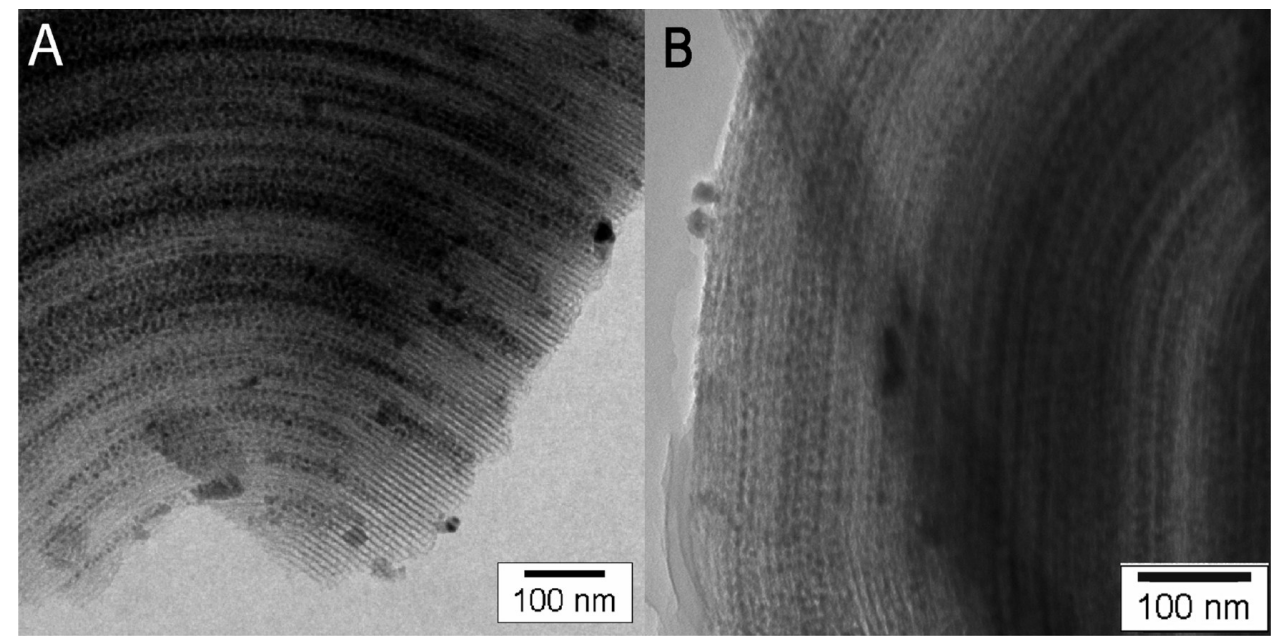

Figure 4. TEM images of $\mathrm{CuO} / \mathrm{SBA}-15$ : (A) heat-treated in $2 \% \mathrm{NO} / \mathrm{N}_{2}$ at a GHSV of $15000 \mathrm{~h}^{-1}$, followed by (B) reduction and reoxidation.

were similar to those for CuSG-NO and suggested that a narrow particle size distribution was obtained. The higher copper surface areas obtained for the CuSBA samples were attributed to the higher specific surface area of the SBA-15 support.

TEM analysis of CuSBA-NO (Figure 4A) showed numerous small $(2-9 \mathrm{~nm}) \mathrm{CuO}$ particles inside the pores in addition to a few $10-30 \mathrm{~nm}$ particles on the external surface, which were retained after reduction and reoxidation (Figure 4B). This was in good agreement with the XRD and $\mathrm{N}_{2} \mathrm{O}$ chemisorption results, as was the case for CuSG-NO. For CuSBA-air (Figure 5A), no particles were observed inside the support pores, while a significant $\mathrm{Cu}$ signal was detected by EDX, indicating that a highly dispersed copper phase was present. Large $\mathrm{CuO}$ agglomerates were observed on the external surface of the support, explaining the sharp XRD diffraction lines (Figure 5B); however, these were a rare occurrence. After reduction and reoxidation (Figure 5C), the highly dispersed $\mathrm{CuO}$ phase remained difficult to image. While a strong $\mathrm{Cu}$ signal was still observed with EDX, only a few small $\mathrm{CuO}$ particles were observed.

Catalytic Activity. The catalytic activities of the CuSG samples after reduction at $230{ }^{\circ} \mathrm{C}$ were measured at 150 and $160{ }^{\circ} \mathrm{C}$ for gas-phase hydrogenation of butanal. Conversions ranged from $10 \%$ to $80 \%$ for the different samples, and within the $72 \mathrm{~h}$ test, deactivation was negligible. The butanol selectivity of the samples was around $97 \%$ in all cases with the exception of CuSG-0, which had a lower selectivity (80\%). The influence of GHSV during calcination on the activity is shown in Figure 6.

The surface area and the activity followed the same trend upon increasing the GHSV during calcination. As with the $\mathrm{Cu}$ surface area, the activity sharply increased going from calcination in stagnant air to a flow of air, while it only slightly increased upon further increase of the space velocity. The activities of the samples thermally treated in different gas atmospheres at a GHSV of $15000 \mathrm{~h}^{-1}$ are shown in Figure 7. In general, similar activities were observed, which coincided with similar copper surface areas. It must be noted that the CuSG-120-air sample showed a slightly lower activity than expected from the surface area, while the NO thermally treated sample has a slightly higher activity than expected. Nevertheless, the gas composition and flow rate during calcination was of great importance for the copper oxide distribution, as is elucidated below.
Vapor Phase Transport. Upon calcination of copper nitrate in a glass reactor in air or $\mathrm{N}_{2}$ flow, a thin black layer of copper species was observed on the inside of the reactor wall. The presence of this black layer indicated that certain copper species were mobile during calcination. Other authors also observed deposition of copper species on a glass IR cell during measurements on gaseous anhydrous copper nitrate above $225^{\circ} \mathrm{C} .{ }^{37}$ The similarity between the observations could indicate anhydrous copper nitrate was formed during our calcination experiments. This black layer on the glass was not observed during calcination in a $2 \% \mathrm{NO} / \mathrm{N}_{2}$ flow, indicating $\mathrm{NO}$ effectively inhibited vaporphase transport of copper species. While the black layer on the glass indicated copper was transported from the sample to the reactor, X-ray fluorescence (XRF) elemental analysis (data not shown) did not reveal any loss of copper within experimental error, suggesting net transport from the sample was limited.

The vapor-phase transport was confirmed by the following experiment. A glass reactor was loaded with a thin layer of copper nitrate trihydrate, then a layer of glass wool, followed by a layer of silica gel. Subsequently, an up-flow heat treatment in $\mathrm{N}_{2}$ or $\mathrm{NO}$ was performed. Above $200{ }^{\circ} \mathrm{C}$ during thermal treatment in $\mathrm{N}_{2}$, the glass wool and the bottom part of the silica started to turn black and the top layers green, indicating transport and deposition of $\mathrm{Cu}$ species. We note that a large part of the $\mathrm{CuO}$ was still located at the bottom after completion of the calcination, indicating only a small part of the copper had been transported through the glass wool. In contrast, calcination in NO left both the glass wool and silica completely white, confirming $\mathrm{NO}$ effectively prevented the formation of gaseous intermediates during calcination. To elucidate the origin of this difference in mobility, the phase evolution was further investigated by in situ DRIFTS and XRD.

In Situ X-ray Diffraction. Figure 8 shows the XRD patterns recorded during thermal treatment of copper nitrate on SBA-15 in $10 \% \mathrm{O}_{2} / \mathrm{N}_{2}$ or $10 \% \mathrm{NO} / \mathrm{He}$ flow. While these studies were performed on samples with slightly lower loadings, this is not expected to influence the copper nitrate genesis. Both measurements showed two identifiable crystalline phases. First $\mathrm{Cu}_{2^{-}}$ $(\mathrm{OH})_{3} \mathrm{NO}_{3}$ was formed as an intermediate phase, which subsequently decomposed into $\mathrm{CuO}$.

$\mathrm{Cu}_{2}(\mathrm{OH})_{3} \mathrm{NO}_{3}\left(\begin{array}{llll}0 & 0 & 1\end{array}\right)$ and $\mathrm{CuO}\left(\begin{array}{lll}1 & 1 & 1\end{array}\right)$ diffraction lines were normalized to the maximum peak area during thermal treatment 


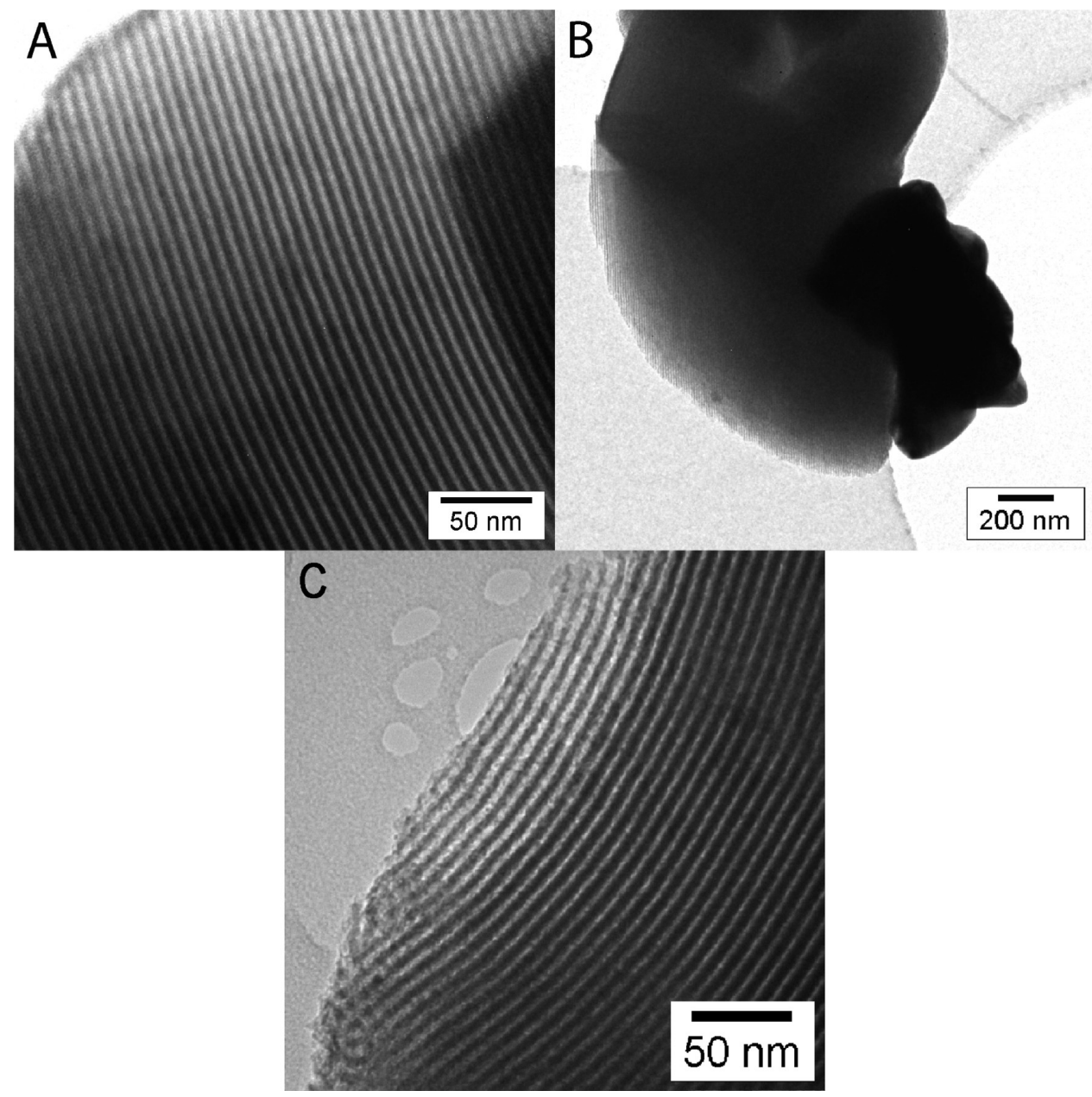

Figure 5. TEM images of CuO/SBA-15: (A, B) after calcination in air at a GHSV of $15000 \mathrm{~h}^{-1}$, followed by (C) reduction and reoxidation.

and plotted as a function of temperature in Figure 9. During $\mathrm{O}_{2} /$ $\mathrm{N}_{2}$ thermal treatment, the $\mathrm{Cu}_{2}(\mathrm{OH})_{3} \mathrm{NO}_{3}$ diffraction lines completely disappeared prior to the appearance of $\mathrm{CuO}$ diffraction lines. This result is in agreement with the proposed formation of a molecular intermediate prior to decomposition to $\mathrm{CuO}$. In the $\mathrm{NO}$ treatment, the $\mathrm{Cu}_{2}(\mathrm{OH})_{3} \mathrm{NO}_{3}$ phase already formed at lower temperatures and was more stable to higher temperatures. Moreover, the $\mathrm{Cu}_{2}(\mathrm{OH})_{3} \mathrm{NO}_{3}$ diffraction lines gradually decreased in intensity concurrently with a gradual increase in $\mathrm{CuO}$ intensity, indicating direct conversion of one crystalline phase into the other. This is also in agreement with the absence of black deposits on the glass reactor. The nature of the possible intermediate that was formed during $\mathrm{O}_{2} / \mathrm{N}_{2}$ thermal treatment was further investigated by diffuse reflectance Fourier transform infrared (DRIFT) spectroscopy.

In Situ Diffuse Reflectance Fourier Transform Infrared Spectroscopy. Figure 10 depicts the spectra recorded during calcination of copper nitrate on SBA-15 in a $1 \% \mathrm{NO} / \mathrm{He}$ flow. The spectra recorded during calcination in a $10 \% \mathrm{NO} / \mathrm{He}$ flow did not significantly differ from those obtained in a $1 \% \mathrm{NO} / \mathrm{He}$ flow; therefore, the former will not be discussed. In addition, experiments with silica gel instead of SBA-15 did not show any significant differences, confirming that the copper nitrate chemistry is similar for both supports.

At room temperature, the spectra showed a broad band in the hydroxyl region due to the presence of water in the sample. The $v_{4}\left(\mathrm{NO}_{3}{ }^{-}\right)$stretch vibration band was observed at $1500 \mathrm{~cm}^{-1}$, which was ascribed to copper nitrate hydrate. The deviation from bulk copper nitrate trihydrate, which has been reported to show one single degenerate $v_{3}$ band at $1387 \mathrm{~cm}^{-1}$, indicated the symmetry of the nitrate groups had changed from $D_{3 h}$ to $C_{2 v}$. This suggested an interaction of the support with copper nitrate hydrate with concomitant stronger coordination of the nitrate groups to the copper. ${ }^{38}$ At $50{ }^{\circ} \mathrm{C}$, three new bands appeared, two $\mathrm{O}-\mathrm{H}$ bands at 3550 and $3480 \mathrm{~cm}^{-1}$ and a peak at $1430 \mathrm{~cm}^{-1}$, assigned to the $v_{\mathrm{OH}}$ and $\nu_{4}\left(\mathrm{NO}_{3}{ }^{-}\right)$vibrations of copper hydroxynitrate, respectively. ${ }^{32,39}$ The appearance of a small $v_{\text {as }}\left(\mathrm{NO}_{2}\right)$ band at $1612 \mathrm{~cm}^{-1}$ due to evolved $\mathrm{NO}_{2}$ confirmed significant decomposition already took place at low temperature. The peak attributed to hydrated copper nitrate rapidly disappeared when the temperature was increased to $100^{\circ} \mathrm{C}$, and the copper hydroxynitrate phase dominated. Further temperature increase caused a gradual decline in the intensity of these bands, in agreement with the in situ $\mathrm{XRD}$ results. Since copper hydroxynitrate was formed rapidly upon heating, it was expected to form at room temperature under $\mathrm{NO}$ as well. This was confirmed by keeping a sample at $30{ }^{\circ} \mathrm{C}$ while introducing $\mathrm{NO}$; after $30 \mathrm{~min}$, basic copper nitrate was almost exclusively present in the sample (data not shown). Thus, we propose the phase evolution of copper nitrate in NO to proceed as follows:

$$
\mathrm{Cu}\left(\mathrm{NO}_{3}\right)_{2} \cdot 3 \mathrm{H}_{2} \mathrm{O} \stackrel{30^{\circ} \mathrm{C}}{\longrightarrow} \mathrm{Cu}_{2} \mathrm{NO}_{3}(\mathrm{OH})_{3} \stackrel{200-230^{\circ} \mathrm{C}}{\longrightarrow} \mathrm{CuO}
$$




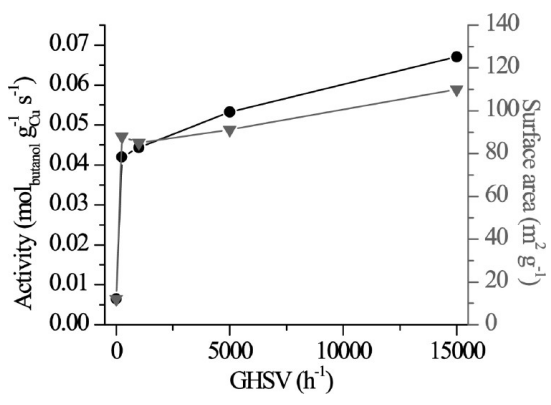

Figure 6. Copper weight normalized activity for butanal hydrogenation at $160{ }^{\circ} \mathrm{C}(0)$ as a function of air flow rate during calcination. Specific copper surface area $(\boldsymbol{\nabla})$ is also shown. Butanal liquid space velocity $=$ $25 \mathrm{~h}^{-1}\left(\mathrm{H}_{2} /\right.$ butanal $\left.=10 \mathrm{~mol} / \mathrm{mol}\right)$.

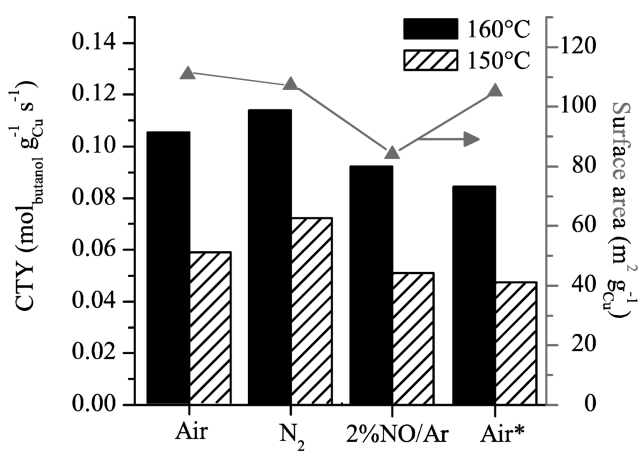

Figure 7. Copper weight normalized activity for butanal hydrogenation and copper surface area $(\boldsymbol{\Delta})$ as a function of the gas atmosphere during thermal treatment $\left(\mathrm{GHSV}=15000 \mathrm{~h}^{-1}\right)$. Butanal liquid space velocity $=$ $50 \mathrm{~h}^{-1}\left(\mathrm{H}_{2} /\right.$ butanal $\left.=10 \mathrm{~mol} / \mathrm{mol}\right)$. ${ }^{*}$ Dried at $120^{\circ} \mathrm{C}$.
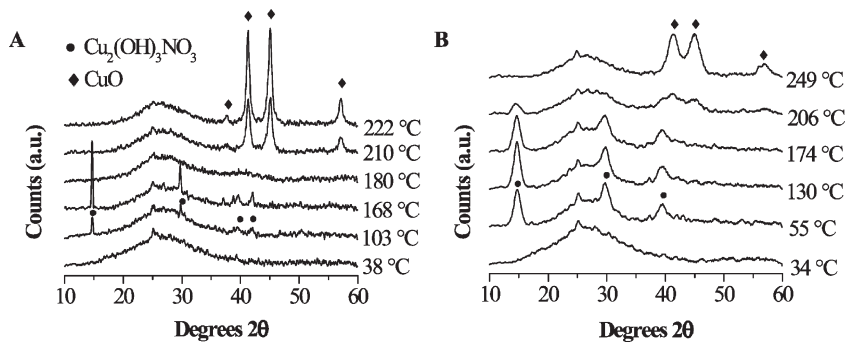

Figure 8. Diffraction patterns recorded during thermal treatment of copper nitrate on SBA-15 in (A) $10 \% \mathrm{O}_{2} / \mathrm{N}_{2}$ and (B) $10 \% \mathrm{NO} / \mathrm{He}$.

The spectra recorded during the thermal treatment of copper nitrate on SBA-15 in an $\mathrm{N}_{2}$ flow (Figure 11) are distinctly different from those in NO. Addition of $\mathrm{O}_{2}$ to the stream of $\mathrm{N}_{2}$ did not significantly affect the acquired spectra, and therefore only those obtained in an $\mathrm{N}_{2}$ flow are discussed.

In an $\mathrm{N}_{2}$ flow, only dehydration was observed until, at $120^{\circ} \mathrm{C}$, the three copper hydroxynitrate bands appeared at 3550, 3450, and $1450 \mathrm{~cm}^{-1}$. In addition, a new band that was hardly observed in $\mathrm{NO}$ developed around $1611 \mathrm{~cm}^{-1}$. At $220{ }^{\circ} \mathrm{C}$, the copper hydroxynitrate decomposed while simultaneously the band at $1611 \mathrm{~cm}^{-1}$ became more intense, confirming that the copper hydroxynitrate was converted into another intermediate before decomposing into $\mathrm{CuO}$. At the same temperatures, the $v_{\mathrm{SiOH}}$

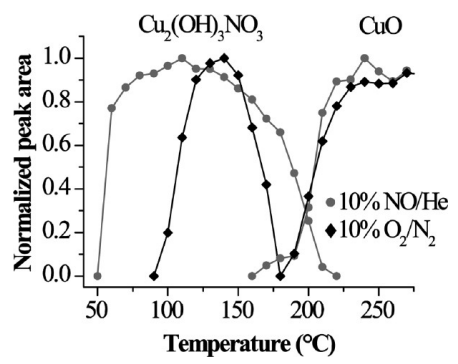

Figure 9. Normalized $14.6^{\circ}\left[\mathrm{Cu}_{2}(\mathrm{OH})_{3} \mathrm{NO}_{3}\right]$ and $45.1^{\circ}(\mathrm{CuO}) 2 \theta$ peak areas as a function of temperature for copper nitrate on SBA-15 samples.

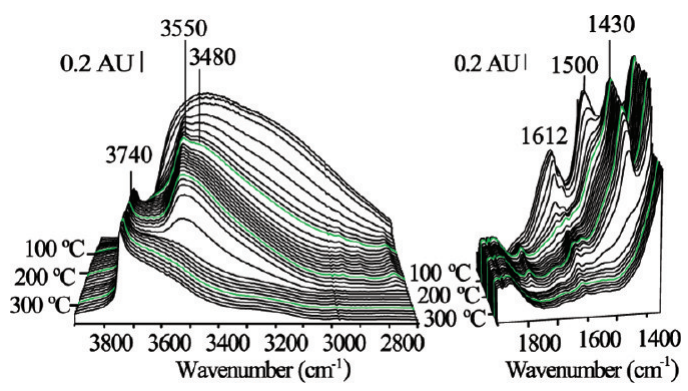

Figure 10. DRIFT spectra recorded during calcination of copper nitrate on SBA- 15 in a $1 \% \mathrm{NO} / \mathrm{He}$ flow.

band at $3742 \mathrm{~cm}^{-1}$, corresponding to free silanol groups, decreased in intensity, which was not observed for the NO thermal treatment.

The evolution of the $v_{\mathrm{SiOH}}$ band for the two measurements is plotted in Figure 12. Here, the intensity normalized on the maximum intensity during thermal treatment is plotted as a function of temperature. At room temperature, the intensity of the silanol band was low due to interactions with water in the sample, but it gradually increased as water was removed. A large increase in the $v_{\mathrm{SiOH}}$ intensity was observed for both treatments concurrent with the formation of copper hydroxynitrate. In $\mathrm{N}_{2}$ a sharp decrease in intensity upon decomposition of the hydroxynitrate at $220{ }^{\circ} \mathrm{C} \mathrm{N}_{2}$ is clearly visible. Upon decomposition of the intermediate to $\mathrm{CuO}$, it slightly increased again but did not fully recover. A blank experiment with the parent SBA-15 treated in $\mathrm{O}_{2}, \mathrm{~N}_{2}$, or NO indicated that no dehydroxylation took place under these conditions. Thus, the decrease in silanol band intensity could be ascribed to an interaction or reaction with copper species.

At $240{ }^{\circ} \mathrm{C}$ in an $\mathrm{N}_{2}$ flow, the band at $1611 \mathrm{~cm}^{-1}$ and accompanying bands at 1570,1542 , and $1500 \mathrm{~cm}^{-1}$, which form a broad feature, were still present after the hydroxyl vibrations at $3500 \mathrm{~cm}^{-1}$ had largely disappeared (Figure 11), suggesting a dehydrated or even anhydrous copper nitrate intermediate was formed. Liberation of $\mathrm{Cu}\left(\mathrm{NO}_{3}\right)_{2}(\mathrm{~g})$ from copper hydroxynitrate has previously been suggested, ${ }^{37}$ and at least two different structures of $\mathrm{Cu}\left(\mathrm{NO}_{3}\right)_{2}$ have been studied by IR before, although details about the different structures are scarce. ${ }^{40,41}$ Addison and Gatehouse $^{42}$ found bands for $\beta-\mathrm{Cu}\left(\mathrm{NO}_{3}\right)_{2}$ at $1592,1565,1546$, and $1504 \mathrm{~cm}^{-1}$, in fair agreement with the bands found in this work. They attributed the bands at 1565 and $1546 \mathrm{~cm}^{-1}$ to the asymmetric $v_{4}$ but thought the band at $1592 \mathrm{~cm}^{-1}$ originated from the $2 v_{6}$ overtone. Given the original intensity of the 


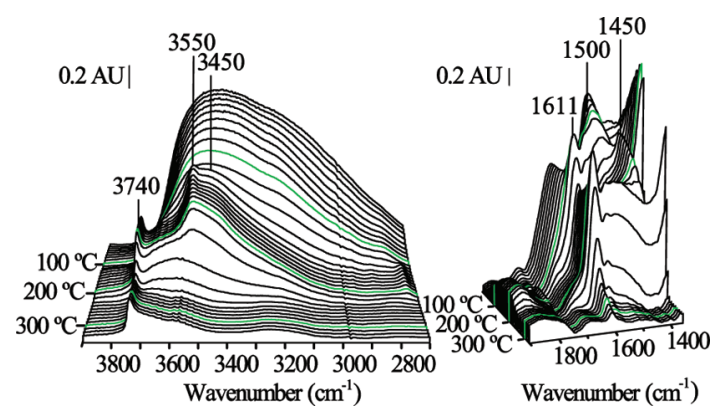

Figure 11. DRIFT spectra recorded during calcination of copper nitrate on SBA-15 in an $\mathrm{N}_{2}$ flow.

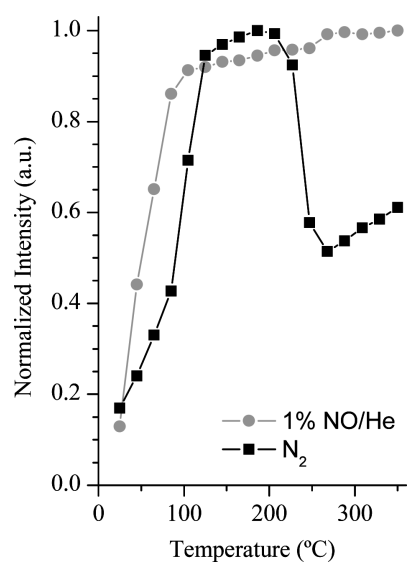

Figure 12. Intensity of the silanol $v_{\mathrm{OH}}$ band at $3745 \mathrm{~cm}^{-1}$ as a function of temperature during calcination of copper nitrate on SBA-15 in an $\mathrm{N}_{2}$ (ם) or $1 \% \mathrm{NO} / \mathrm{He}(\mathbf{O})$ flow.

$v_{6}$ vibration they report, this is actually unlikely; the alleged combination band is more intense than the original vibration, whereas overtones are always lower in intensity. Therefore, it is more likely this is also a $v_{4}$ nitrate band, which was also proposed by Logan and Simpson ${ }^{41}$ after observing the same bands.

\section{DISCUSSION}

Combining the assignment of $\beta$-anhydrous copper nitrate with the redispersion of copper nitrate species during calcination, we propose the copper nitrate evolution in the presence of $\mathrm{N}_{2}$ proceeds as shown in eq 2 . As the anhydrous copper nitrate bands were already observed above $110^{\circ} \mathrm{C}$, it is likely that part of the decomposition occurs via eq 3 . Especially at higher flow rates, where hydrolysis is suppressed, the latter route might be dominant.

$$
\begin{aligned}
& \mathrm{Cu}\left(\mathrm{NO}_{3}\right)_{2} \cdot 3 \mathrm{H}_{2} \mathrm{O}(\mathrm{s}) \stackrel{110^{\circ} \mathrm{C}}{\longrightarrow} \mathrm{Cu}_{2} \mathrm{NO}_{3}(\mathrm{OH})_{3}(\mathrm{~s}) \stackrel{150-230^{\circ} \mathrm{C}}{\longrightarrow} \\
& \mathrm{Cu}\left(\mathrm{NO}_{3}\right)_{2}(\mathrm{~s}, \mathrm{~g}), \mathrm{CuO}(\mathrm{s}) \stackrel{180-300^{\circ} \mathrm{C}}{\longrightarrow} \mathrm{CuO}(\mathrm{s}) \\
& \mathrm{Cu}\left(\mathrm{NO}_{3}\right)_{2} \cdot 3 \mathrm{H}_{2} \mathrm{O}(\mathrm{s}) \stackrel{110-210^{\circ} \mathrm{C}}{\longrightarrow} \mathrm{Cu}\left(\mathrm{NO}_{3}\right)_{2}(\mathrm{~s}, \mathrm{~g}) \stackrel{180-300^{\circ} \mathrm{C}}{\longrightarrow} \mathrm{CuO}(\mathrm{s})
\end{aligned}
$$

It is now postulated that the relatively high dispersions that are obtained via thermal treatment in air or $\mathrm{N}_{2}$ flow result from surface migration or sublimation of anhydrous copper nitrate at $\sim 220^{\circ} \mathrm{C}$ and decomposition upon contact with a silica surface. We tentatively propose the observed loss of silanol groups due to their reaction with anhydrous copper nitrate. Assuming a silanol density of $2 \mathrm{OH}$ groups $\cdot \mathrm{nm}^{-2}$ and grafting of one $\mathrm{Cu}$ onto two silanol groups, up to a third of the $\mathrm{Cu}$ can be atomically dispersed in this way. We tentatively propose the overall redispersion and decomposition reaction to proceed as follows:

$$
\begin{aligned}
& \mathrm{Cu}\left(\mathrm{NO}_{3}\right)_{2}(\mathrm{~g})+2 \mathrm{Si}(\mathrm{OH})(\mathrm{s}) \rightarrow(\mathrm{SiO})_{2}-\mathrm{Cu}(\mathrm{II})(\mathrm{s}) \\
& +\mathrm{H}_{2} \mathrm{O}(\mathrm{g})+2 \mathrm{NO}_{2}(\mathrm{~g})+1 /{ }_{2} \mathrm{O}_{2}(\mathrm{~g})
\end{aligned}
$$

The presence of a moderate gas flow is essential to remove water to facilitate dehydration of copper nitrate hydrate and concomitant redispersion of copper species. Although the extent of redispersion could be further enhanced upon thermal treatment at very high gas flows and a switch from air to an $\mathrm{N}_{2}$ atmosphere, the limited increase in dispersion (Figure 6) suggests an optimum exists, which could be dependent on the internal surface area of the support. Why more large crystals are formed in air compared to $\mathrm{N}_{2}$ remains unclear and has not been extensively studied.

This behavior in an air or $\mathrm{N}_{2}$ atmosphere is very different from that previously found for nickel and cobalt. ${ }^{4-45}$ While nickel does form a hydroxynitrate intermediate similar to copper, no redispersion occurred, and consequently poor dispersions and large crystallites were usually obtained after a conventional heat treatment. Cobalt does not normally form the hydroxynitrate as an intermediate species but rather forms an anhydrous nitrate, similar to the phase responsible for the redispersion of copper. However, again in that case, poor dispersions and large crystallites were generally obtained. Interestingly, in an $\mathrm{NO}$ atmosphere all three metal nitrates follow the same decomposition pathway. Previously we have reported that nickel and cobalt nitrates form hydroxynitrate phases in an NO atmosphere, resulting in small crystallites and high dispersions. ${ }^{46,47}$ Here we have again observed the formation of hydroxynitrates and narrow $\mathrm{CuO}$ particle size distributions in NO. However, in the case of copper, even higher dispersions are obtainable in a flow of air or an inert gas.

\section{- CONCLUSIONS}

Silica-supported copper catalysts were prepared via copper nitrate impregnation, drying, calcination, and reduction. The impact of the gas flow rate and gas composition during calcination on the copper nitrate genesis, final metal (oxide) dispersion, and catalytic activity for butanal hydrogenation were studied. A flow of gas during calcination was found to be essential; a moderate flow was already sufficient to achieve a 7-fold increase in specific copper surface area and catalytic activity. It is postulated that water removal during decomposition is essential to prevent agglomeration.

In situ XRD and DRIFTS showed that the composition of the gas flow had a major impact on copper nitrate genesis and final metal oxide dispersion. In a flow of $2 \% \mathrm{NO} / \mathrm{N}_{2}$, copper nitrate hydrate was rapidly and fully converted to small copper hydroxynitrate crystallites. Further temperature increase resulted in decomposition into $\mathrm{CuO}$ particles with an average size of $6-8 \mathrm{~nm}$, which were retained upon reduction. Surprisingly, decomposition in an air flow or $\mathrm{N}_{2}$ flow also yielded high copper oxide dispersions, in contrast to results previously presented for nickel and cobalt. This occurred at least partly via an intermediate that was identified as mobile copper nitrate anhydrate. Surface migration 
or sublimation of this compound during thermal treatment in the presence of a flow resulted in redispersion of the copper nitrate phase, as apparent from deposition on the reactor walls and loss of silanol groups. Due to partial decomposition via poorly dispersed copper hydroxynitrate ( $>25 \mathrm{~nm}$ crystallites), a bimodal distribution was obtained, which resulted in a poor correlation between $\mathrm{CuO}$ crystallite size and $\mathrm{Cu}$ particle size. It is proposed that this mobile phase, which is not observed for cobalt and nickel nitrates, is the origin of the high copper oxide dispersions in $\mathrm{N}_{2}$ and air flow. These results illustrate the importance of in-depth fundamental studies of phase transitions during catalyst preparation.

\section{AUTHOR INFORMATION}

\section{Corresponding Author}

*Phone +31-30-253-6762/7400; fax +31-30-251-1027; e-mail k.p.dejong@uu.nl.

\section{Present Addresses}

${ }^{\ddagger}$ Shell Global Solutions, P.O. Box 38000, 1030 B Amsterdam, The Netherlands.

"Oxford Catalysts Group, 115e Milton Park, Oxford OX14 4RZ, U.K.

\section{ACKNOWLEDGMENT}

We kindly thank Marjan Versluijs-Helder for in situ XRD measurements, Fouad Soulimani for assistance with DRIFT measurements, Heiner Friedrich for TEM analysis, Colin Ranson for copper surface area determination, and David Maclachlan for XRF analysis. Johnson Matthey Catalysts is acknowledged for financial support, and especially Dr. John Casci for his scientific contributions.

\section{REFERENCES}

(1) Ai, M. Appl. Catal. 1984, 11, 259-270.

(2) Guerreiro, E. D.; Gorriz, O. F.; Larsen, G.; Arrúa, L. A. Appl. Catal., A 2000, 204, 33-48.

(3) Guerreiro, E. D.; Gorriz, O. F.; Rivarola, J. B.; Arrúa, L. A. Appl. Catal., A 1997, 165, 259-271.

(4) Guerrero-Ruiz, A.; Rodriguez-Ramos, I.; Fierro, J. L. G. Appl. Catal. 1991, 72, 119-137.

(5) Toupance, T.; Kermarec, M.; Louis, C. J. Phys. Chem. B 2000, 104, 965-972.

(6) Wang, Z.; Liu, Q.; Yu, J.; Wu, T.; Wang, G. Appl. Catal., A 2003, 239, 87-94.

(7) Marchi, A. J.; Fierro, J. L. G.; Santamaría, J.; Monzón, A. Appl. Catal., A 1996, 142, 375-386.

(8) Marchi, A. J.; Gordo, D. A.; Trasarti, A. F.; Apesteguía, C. R. Appl. Catal., A 2003, 249, 53-67.

(9) Suh, M.-J.; Ihm, S.-K. Top. Catal. 2010, 53, 447-454.

(10) Kuijpers, E. G. M.; Tjepkema, R. B.; van der Wal, W. J. J.; Mesters, C. M. A. M.; Spronck, S. F. G. M.; Geus, J. W. Appl. Catal. 1986, 25, 139-147.

(11) Yeragi, D.; Pradhan, N.; Dalai, A. Catal. Lett. 2006, 112, $139-148$.

(12) Chen, L.; Guo, P.; Zhu, L.; Qiao, M.; Shen, W.; Xu, H.; Fan, K. Appl. Catal., A 2009, 356, 129-136.

(13) Huang, Z.; Cui, F.; Kang, H.; Chen, J.; Zhang, X.; Xia, C. Chem. Mater. 2008, 20, 5090-5099.

(14) Herman, R. G.; Klier, K.; Simmons, G. W.; Finn, B. P.; Bulko, J. B.; Kobylinski, T. P. J. Catal. 1979, 56, 407-429.

(15) Liu, X.-M.; Lu, G. Q.; Yan, Z.-F.; Beltramini, J. Ind. Eng. Chem. Res. 2003, 42, 6518-6530.
(16) Kasatkin, I.; Kurr, P.; Kniep, B.; Trunschke, A.; Schlögl, R. Angew. Chem., Int. Ed. 2007, 46, 7324-7327.

(17) Behrens, M.; Furche, A.; Kasatkin, I.; Trunschke, A.; Busser, W.; Muhler, M.; Kniep, B.; Fischer, R.; Schlögl, R. Chem CatChem 2010, 2, 816-818.

(18) Porta, P.; De Rossi, S.; Ferraris, G.; Lo Jacono, M.; Minelli, G.; Moretti, G. J. Catal. 1988, 109, 367-377.

(19) Becker, M.; d'Alnoncourt, R. N.; Kähler, K.; Sekulic, J.; Fischer, R. A.; Muhler, M. Chem. Vapor Deposition 2010, 16, 85-92.

(20) Kurtz, M.; Bauer, N.; Büscher, C.; Wilmer, H.; Hinrichsen, O.; Becker, R.; Rabe, S.; Merz, K.; Driess, M.; Fischer, R.; Muhler, M. Catal. Lett. 2004, 92, 49-52.

(21) Schimpf, S.; Rittermeier, A.; Zhang, X.; Li, Z.-A.; Spasova, M.; van den Berg, M. W. E.; Farle, M.; Wang, Y.; Fischer, R. A.; Muhler, M. Chem CatChem 2010, 2, 214-222.

(22) Sun, Y.; Sermon, P. A. Top. Catal. 1994, 1, 145-151.

(23) van Dillen, A. J.; Terörde, R. J. A. M.; Lensveld, D. J.; Geus, J. W.; de Jong, K. P. J. Catal. 2003, 216, 257-264.

(24) van de Loosdrecht, J.; Barradas, S.; Caricato, E. A.; Ngwenya, N. G.; Nkwanyana, P. S.; Rawat, M. A. S.; Sigwebela, B. H.; van Berge, P. J.; Visagie, J. L. Top. Catal. 2003, 26, 121-127.

(25) Sietsma, J. R. A.; Meeldijk, J. D.; Versluijs-Helder, M.; Broersma, A.; van Dillen, A. J.; de Jongh, P. E.; de Jong, K. P. Chem. Mater. 2008, 20, 2921-2931.

(26) Chu, W.; Wang, L.; Chernavskii, P.; Khodakov, A. Y. Angew. Chem., Int. Ed. 2008, 47, 5052-5055.

(27) Bartholomew, C. H.; Farrauto, R. J. J. Catal. 1976, 45, 41-53.

(28) Louis, C.; Cheng, Z. X.; Che, M. J. Phys. Chem. 1993, 97, $5703-5712$.

(29) Llewellyn, P. L.; Chevrota, V.; Ragaib, J.; Cerclier, O.; Estienne, J.; Rouquerol, F. Solid State lonics 1997, 101-103, 1293-1298.

(30) Sietsma, J. R. A.; Meeldijk, J. D.; den Breejen, J. P.; VersluijsHelder, M.; van Dillen, A. J.; de Jongh, P. E.; de Jong, K. P. Angew. Chem., Int. Ed. 2007, 46, 4547-4549.

(31) Sietsma, J. R. A.; Friedrich, H.; Broersma, A.; Versluijs-Helder, M.; Jos van Dillen, A.; de Jongh, P. E.; de Jong, K. P. J. Catal. 2008, 260, 227-235.

(32) Catillon-Mucherie, S.; Ammari, F.; Krafft, J. M.; Lauron-Pernot, H.; Touroude, R.; Louis, C. J. Phys. Chem. C 2007, 111, 11619-11626.

(33) Catillon-Mucherie, S.; Lauron-Pernot, H.; Louis, C. J. Phys. Chem. C 2010, 114, 11140-11147.

(34) Sietsma, J. R. A.; Meeldijk, J. D.; Versluijs-Helder, M.; Broersma, A.; van Dillen, A. J.; de Jongh, P. E.; de Jong, K. P. Chem. Mater. 2008, 20, 2921-2931.

(35) Zhao, D.; Feng, J.; Huo, Q.; Melosh, N.; Fredrickson, G. H.; Chmelka, B. F.; Stucky, G. D. Science 1998, 279, 548-552.

(36) Friedrich, H.; Sietsma, J. R. A.; de Jongh, P. E.; Verkley, A. J.; de Jong, K. P. J. Am. Chem. Soc. 2007, 129, 10249-10254.

(37) Addison, C. C.; Hathaway, B. J. J. Chem. Soc. 1958, 3099-3106.

(38) Hadjiivanov, K. I. Catal. Rev. Sci. Eng. 2000, 42, 71-144.

(39) Zotov, N.; Petrov, K.; Dimitrova-Pankanova, M. J. Phys. Chem. Solids 1990, 51, 1199-1205.

(40) James, C. W. Inorg. Nucl. Chem. Lett. 1969, 5, 609-612.

(41) Logan, N.; Simpson, W. B. Spectrochim. Acta 1965, 21, 857-860.

(42) Addison, C. C.; Gatehouse, B. M. J. Chem. Soc. 1960, 125, 613-616.

(43) Wolters, M.; Munnik, P.; Bitter, J. H.; de Jongh, P. E.; de Jong, K. P. J. Phys. Chem. C 2011, 115, 3332-3339.

(44) Wolters, M.; Daly, H.; Goguet, A.; Meunier, F. C.; Hardacre, C.; Bitter, J. H.; de Jongh, P. E.; de Jong, K. P. J. Phys. Chem. C 2010, 114, 7839-7845.

(45) Wolters, M.; Contreras Andrade, I. C. A.; Munnik, P.; Bitter, J. H.; de Jongh, P. E.; de Jong, K. P. Stud. Surf. Sci. Catal. 2010, 175, 69-76.

(46) den Breejen, J. P.; Sietsma, J. R. A.; Friedrich, H.; Bitter, J. H.; de Jong, K. P. J. Catal. 2010, 270, 146-152.

(47) Wolters, M.; van Grotel, L. J. W.; Eggenhuisen, T. M.; Sietsma, J. R. A.; de Jong, K. P.; de Jongh, P. E. Catal. Today 2010, 163, 27-32. 